Neuroepidemiology 2008:31:138

DOI: $10.1159 / 000151515$

\section{Body Mass Index, Cholesterol Level and Poststroke Mortality}

\author{
Luca Mascitellia , Francesca Pezzettab ${ }^{\mathrm{b}}$, Mark R. Goldstein ${ }^{c}$ \\ ${ }^{a}$ Medical Service, Comando Brigata Alpina Julia, Udine, and \\ ${ }^{\mathrm{b}}$ Cardiology Service, Ospedale di Tolmezzo, Tolmezzo, Italy; \\ ${ }^{\text {'}}$ Fountain Medical Court, Bonita Springs, Fla., USA
}

Olsen et al. [1] found that the body mass index (BMI) in patients with stroke was inversely related to total poststroke mortality. The mechanism underlying this association is however not clearly understood. We suggest that one possibility might be related to the higher cholesterol levels associated with high BMI.

It is well known that cholesterol levels are inversely related to all-cause mortality in middle-aged and older men and women, and a reverse causation is unlikely to account for this finding [2]. It may result from an increase in both cancer and noncardiovascular disease mortality with lower cholesterol levels.

In particular, higher serum cholesterol concentrations have been shown to be associated with lower short-term mortality after stroke [3-5]. Furthermore, Olsen et al. [6] have recently reported an inverse relation between cholesterol and stroke severity, and consequently with poststroke mortality, thus suggesting that higher cholesterol favors the development of small-vessel disease and thereby less severe strokes associated with lower mortality.

Therefore, higher levels of cholesterol might be a plausible mechanism for the inverse relationship between BMI and poststroke mortality.

\section{References}

1 Olsen TS, Dehlendorff C, Petersen HG, Andersen KK: Body mass index and poststroke mortality. Neuroepidemiology 2008;30:93-100.

2 Ulmer H, Kelleher C, Diem G, Concin H: Why Eve is not Adam: prospective follow-up in 149,650 women and men of cholesterol and other risk factors related to cardiovascular and all-cause mortality. J Women's Health 2004;13:41-53.

3 Dyker AG, Weir CJ, Lees KR: Influence of cholesterol on survival after stroke: retrospective study. BMJ 1997;314:1584-1588.

4 Vauthey C, de Freitas GR, van Melle G, Devuyst G, Bogousslavsky J: Better outcome after stroke with higher serum cholesterol levels. Neurology 2000;54:1944-1949.

5 Zuliani G, Cherubini A, Atti AR, Blè A, Vavalle C, Todaro FD, Benditti C, Volpato S, Marinescu MG, Senin U, Fellin R: Low cholesterol levels are associated with short-term mortality in older patients with ischemic stroke. J Gerontol A Biol Sci Med Sci 2004;59A:293-297.

6 Olsen TS, Christensen RH, Kammersgaard LP, Andersen KK: Higher total serum cholesterol levels are associated with less severe strokes and lower all-cause mortality: ten-year follow-up of ischemic strokes in the Copenhagen Stroke Study. Stroke 2007;38:2646-2651.

Luca Mascitelli, MD, Medical Service, Comando Brigata Alpina Julia, 8 , Via S. Agostino, IT-33100 Udine (Italy)

Tel. +39 432584 044, Fax +39 432584 053, E-Mail lumasci@libero.it

\section{Neuroepidemiology 2008;31:138 \\ DOI: 10.1159/000151516}

\section{Reply to the Letter by Mascitelli et al.: Body Mass Index, Cholesterol Level and Poststroke Mortality}

\author{
Tom Skyhøj Olsen ${ }^{\mathrm{a}}$, Christian Dehlendorff ${ }^{\mathrm{b}}$, \\ Hans Gregers Petersen ${ }^{\mathrm{b}}$, Klaus Kaae Andersen ${ }^{\mathrm{b}}$ \\ ${ }^{\text {a S}}$ troke Unit, Hvidovre University Hospital, Hvidovre, and \\ bInformatics and Mathematical Modelling, Section for Statistics, \\ Technical University of Denmark, Lyngby, Denmark
}

We appreciate the thoughtful comments of Mascitelli et al. In our paper we did not adjust for serum cholesterol as this variable was not available in our database. However, for the purpose of our study adjustment for serum cholesterol is not necessary. Along with hypertension and diabetes, cholesterol is a mediator and not a confounder. Hence, these variables should not be adjusted for in the survival model, as they are part of the causal chain between $\mathrm{BMI}$ and death/survival. For this reason we presented two models, one including all the variables and one excluding mediators. The latter, we believe, is the most correct one. Both models, however, gave the same result: overweight persons with stroke had a better outcome than those who were underweight and normal weight. Moreover, compared to normal-weight individuals, survival was better in the obese and very obese individuals with stroke.

Whether cholesterol, as suggested by Mascitelli et al., is responsible for the inverse relationship between BMI and survival is still not clarified, we believe. The possibility exists but other unknown elements in the causal chain are possibilities as well. Our study showed a clear association with BMI, diabetes and hypertension, both risk factors associated with an increased mortality rate. So, there is no doubt that the mortality rate is increased in many overweight and obese persons. However, our study shows that this is most likely due to hypertension and diabetes and not overweight and obesity per se. It can be hypothesized that overweight and obesity signal a lifestyle, which is leading to hypertension and diabetes and thereby decreased survival. If, however, an overweight or obese person has a 'healthy' lifestyle, survival is not endangered.

We agree with Mascitelli et al. in their interpretation of our data. In patients with stroke the majority of poststroke deaths are caused by another stroke [1]. The risk of stroke is increased in overweight and obese persons but these strokes may be caused by small-vessel disease rather that large-vessel disease [1]. This might in part explain the lower mortality associated with overweight and obesity.

\section{References}

1 Mascitelli L, Pezzetta F, Goldstein MR: Body mass index, cholesterol level and poststroke mortality. Neuroepidemiology 2008;31:138.

Tom Skyhøj Olsen, MD, PhD

Stroke Unit, Hvidovre University Hospital

DK-2650 Hvidovre (Denmark)

Tel. +453632 2456, Fax +4536323312

E-Mail tom.skyhoej.olsen@hvh.regionh.dk

\section{KARGER}

Fax +41613061234 E-Mail karger@karger.ch www.karger.com
(C) 2008 S. Karger AG, Base

0251-5350/08/0312-0138\$24.50/0 